\title{
2010 Local Elections - A Serious Warning to Parliamentary Political Parties
}

\author{
MARJAN BREZOVŠEK \& LEA SMERKOLJ
}

\begin{abstract}
The fundamental principle of the modern local self-government system is the transfer of decision-making on public matters to the lowest possible level, enabling citizens to identify themselves with the local political environment as much as possible. Local government is considered democratic if its performance is decisively and directly or indirectly influenced (through elected representatives that are entrusted with local-level tasks) by the citizens themselves. Local elections are frequently compared to national elections, even though data show that local elections have their own peculiarities that cannot be applied to the national level. This is especially true regarding the dominant role of non-partisan candidates, and the ever decreasing support for political parties. Without the latter, one cannot even imagine the national level of government because they represent the key actors in national democratic political systems. Regarding the degree of trust in political parties at the local level, one can identify a trend indicating that citizens have gained a greater awareness that local-level politics is not related to party adherence, and that individuals' personalities and their alleged apolitical character is coming increasingly to the fore, which is reflected by a high number of eligible nonpartisan candidates. Therefore, one can see in Slovenia that people have become frustrated over the politicisation of local-level politics by expressing an ever-greater desire to support non-partisan candidates for the leaders of their local communities. Thus, they seek the candidates whose performance is not politically marked so that they can more easily identify themselves with them.
\end{abstract}

KEYWORDS: - local democracy - local elections - parliamentary elections • political parties $\bullet$ non-partisan candidates $\bullet$ Slovenia

CorRespondence AdDress: Associate professor Marjan Brezovšek, Ph. D., Faculty of Social Sciences, Kardeljeva ploščad 5, SI-1000 Ljubljana, Slovenia, email: marjan.brezovsek@fdv.uni-lj. Assistant professor Lea Smerkolj, Faculty of Social Sciences, Kardeljeva ploščad 5, SI-1000 Ljubljana, Slovenia, email: lea.smerkolj@fdv.uni-lj.si. 
J. S. Mill (1861) denotes representative democracy as the essence of national and local-level democracy. Thus, democracy should have a strong local dimension because the fundamental democratic institution is not the state (Stoker, 2004: 50), but rather local self-government that is of key importance to the lives of citizens. Namely, local authority is considered democratic if its performance is decisively and directly or indirectly influenced (through the duty bearers elected at the local level) by the citizens themselves. In this manner, local-level politics represents the setting in which democracy is formed, while at the same time, it has a high capability of creating people's identity or a sense of allegiance.

The fundamental principle of the modern system of local self-government is the transfer of decision-making on public matters to the lowest possible level, enabling residents to identify themselves with the local political environment as much as possible (Bačlija, 2007: 50). The strategy of decentralisation of power and resources is described by some authors as the "new localism" (Stoker, 2004: 2 ). The latter concept explains the change at the local level in terms of local autonomy and local-level democracy whereby local government is considered the most accessible level of government where citizens can participate politically. Local-level democratic processes must be open, and citizens must recognise that it is their right and duty to participate in public life at the local level (Stoker, 1996: 189). The existence of a strong localism in Slovenia can be traced back to the $1990 \mathrm{~s}$ as the tendencies towards the establishment of individual municipalities were continually surfacing (Bačlija 2007, 62). There was also an increasing number of non-partisan ${ }^{1}$ candidacies of local actors who represented an alternative to political parties in local elections during that time frame.

Local elections are frequently compared to national elections. However, local elections exhibit certain peculiarities that cannot be applied to the national level. Local elections take place in a much smaller community than national ones. This affects both the organisation of elections and their perceived meaning. It makes sense to stress that local elections are actually comprised of multiple types of elections, namely, municipal council elections, village, district and parish council elections, and mayoral elections. The different nature of local self-government and its bodies places political parties and their operation in a different role (from that played at the national level) in regard to the performance of indirect democracy. Local-level politics is the process through which residents participate in the performance of local self-government. Furthermore, it is a way for citizens to assert themselves in public life, and it is not the fight for political power, the fundamental characteristic of politics and party behaviour at the national level (Grad, 2001). Thus, local-level politics faces the local-level significance issues that are to a lesser extent dependent on political standpoints and views. The role of political parties in local elections is less significant than in parliamentary 
elections, a fact evidenced by increasing eligibility of non-partisan local candidates who have no representatives of their own at the national level.

The majority of people from countries with a representative democracy see the parties as the main actors needed for efficient performance of a political system (Holmberg, 2003: 288). Political parties must be sure that they consistently maintain fairly stable support from voters because, in the opposite case, the decline in the support of a democratic regime could occur (Holmberg, 2003: 298). The question that follows is whether political parties ought to be present at both the national and local levels. The progressives resolutely support the idea that political parties should retreat from local elections, which would disable the power of political organisations, thereby making municipal authorities more accountable to the local population, and protecting the latter from destructive outside interference. In their view, partisanship and political ties have no positive function. On the contrary, political scientists argue that political parties not only play a positive role, but they are also essential for a strong democracy at the local level because political connections offer strong cognitive information (Schaffner et. al., 2001: 8).

A typical example of non-partisan local elections can be found in certain states within the United States. These elections illustrate that a non-partisan scheme, limiting the participation of political parties at the local level, leads to more efficient and accessible local administration. The aim of non-partisan elections lies in the insulation of local elections from national party politics, the prevention of corruption, and establishment of an alternative structure of local administration (Northup, 1987: 1677-78). The latter objective is specifically based upon the fact that national issues are often irrelevant to local elections, and that local election systems should promote the consideration of local-level issues. Some advocates of non-partisan local elections actually say that local issues, contrary to national issues, are not political but administrative (Lee, quot. in Northup, 1987: 1679). The purpose of introducing non-partisan elections is to transform local selfgovernment from a political to an administrative form. Thus, it would operate according to the economic principle of efficiency, regardless of party politics (Cassel, 1987: 247). Yet, even here, an independence problem arises because candidates are often recruited from the ranks of political parties.

A direct projection of election results, ranging from local to national levels, can be misleading (Haček, 2007: 34). However, one must not ignore the indirect influence local elections have on the political atmosphere among voters. This conclusion can be justified by the election outcome for the Liberal Democracy of Slovenia that won the highest percentage of votes in the 2002 local elections. It subsequently underwent a significant decline in parliamentary elections in 2004, and in local elections in 2006. The poor local election results in 2006 brought about some changes in the party operation at the national level as well. Some members left the party, and in 2007, they established a new party called ZARES 
that first appeared in the 2010 local elections. However, it achieved no significant results. In our comparative analysis of past elections, we focus on the analysis of the local election trends since 1994 when local self-government was reestablished. We specifically analyse certain idiosyncrasies of the local elections held in October 2010.

\section{Election Results for Political Parties in local Elections from 1994 to 2010}

\subsection{Voter Turnout Rates with Respect to the Size of Municipalities}

Prior to analysing election results, it is noteworthy to remember that the first elections to municipal bodies (considered as the fundamental units of local selfgovernment in Slovenia) were held in 147 municipalities on 4 December 1994. In the subsequent election in 1998, however, the Slovene territory was already divided into 192 municipalities, and four years later, another municipality was established. The trend persisted until the 2006 local elections (210 municipalities). However, it did not continue all the way to the most recent local elections in 2010 when no additional new municipalities were established. The recent amendments to the Local Government $\mathrm{Act}^{2}$ are intended to prevent further fragmentation of Slovenia. The condition of the minimum number of residents (5000) residing in a territory where a new municipality is scheduled to be established has become more stringent because no exceptions are allowed to this rule. In 2010, the number of municipalities did not increase, even though referendums regarding the establishment of five new municipalities were held in 2009. Out of the five proposals that were dealt with, only two succeeded. Yet matters were complicated when decisions had to be adopted by the Parliament that actually establishes municipalities by adopting an act. Thus, prior to the 2010 local election, the number of municipalities remained unchanged.

Prior to local elections, the number of municipalities, especially those with a relatively small number of residents, increased. The Slovenian municipalities differ in the voting systems they use because in those municipalities where fewer than 12 municipal councillors have to be elected, the majority electoral system is applied, whereas in the municipalities where 12 or more municipal councillors have to be elected, a proportional representation system is used. ${ }^{3}$ In most of the newly established municipalities, the majority system is used. It works by choosing individual candidates, and it is not significantly influenced by political parties. 
Table 1: Number of municipalities and the type of election system

\begin{tabular}{llllll}
\hline & $\mathbf{1 9 9 4}$ & $\mathbf{1 9 9 8}$ & $\mathbf{2 0 0 2}$ & $\mathbf{2 0 0 6}$ & $\mathbf{2 0 1 0}$ \\
\hline Number of Municipalities - Total & 147 & 192 & 193 & 210 & 210 \\
Urban Municipalities & 11 & 11 & 11 & 11 & 11 \\
Other Municipalities & 136 & 181 & 182 & 199 & 199 \\
& & & & & \\
Municipalities with proportional representation system & 131 & 144 & 145 & 150 & 149 \\
Municipalities with majority election system & 16 & 48 & 48 & 60 & 61 \\
\hline
\end{tabular}

Source: Data from National Electoral Commission for the year 2010 and Statistical Office of the Republic of Slovenia, published in the publication "Lokalne volitve 1994-2006" ("1994-2006 Local Elections"), Statistical Office of the Republic of Slovenia, Ljubljana.

As shown in the tables below, we divided the Slovenian municipalities according to the size of their population. This process is in accordance with Article 116 of the Local Elections Act (2007). It also establishes the number of municipal council members. Resident participation in the local decision-making process represents the most stable foundation for legitimising local institutions, and for serving as an important indicator of democratic governance. The prevailing reasons for participation in local elections are, according to research findings 4 , performance of citizen duty, the possibility of influencing the future of a municipality, and a wish to vote for one's own candidate. Voting for one's own political party has much smaller support. This also serves as a prelude to the most frequent reasons for citizens not to cast a ballot in local elections: disappointment over politics, the opinion that an individual's vote makes no difference to anything, and general dissatisfaction with available candidates. The low-voter turnout results reflect the weakened democratic participation, especially at the level of local self-government because those representatives who are eventually elected actually receive the support of a minority of the overall constituency (Rallings \& Thrasher, quot. in Haček, 2004: 29). 
Table 2: Voter turnout according to the size of municipalities comparison of local elections during the 1994-2010 period

\begin{tabular}{llllll}
\hline $\begin{array}{l}\text { Size of a Municipality } \\
\text { (number of residents) }\end{array}$ & $\begin{array}{l}\text { \% Voter } \\
\text { turnout } \\
(\mathbf{1 9 9 4 )}\end{array}$ & $\begin{array}{l}\text { \% Voter } \\
\text { turnout } \\
(\mathbf{1 9 9 8})\end{array}$ & $\begin{array}{l}\text { \% Voter } \\
\text { turnout } \\
(\mathbf{2 0 0 2})\end{array}$ & $\begin{array}{l}\text { \% Voter } \\
\text { turnout } \\
(\mathbf{2 0 0 6})\end{array}$ & $\begin{array}{l}\text { \%oter } \\
\text { turnout } \\
(\mathbf{2 0 1 0})\end{array}$ \\
\hline Up to 3,000 & 67.1 & 67.8 & 74.9 & 66 & 61.1 \\
$3,001-5,000$ & 68.9 & 67 & 75.9 & 64.6 & 60 \\
$5,001-10,000$ & 66.2 & 64.3 & 75.5 & 62.4 & 55 \\
$10,001-15,000$ & 69.6 & 60.1 & 73.9 & 54.9 & 50.7 \\
$15,001-20,000$ & 64.4 & 60.1 & 73.1 & 52.5 & 52.1 \\
$20,001-30,000$ & 64.9 & 57.3 & 70.3 & 53.3 & 46.8 \\
$30,001-100,000$ & 59.4 & 58.5 & 71 & 53.6 & 45 \\
Above 100,000 & 55.3 & 45.2 & 65.8 & 54.5 & 44.4 \\
\hline Total (State as a Whole) & $\mathbf{6 2 . 7}$ & $\mathbf{5 8 . 3}$ & $\mathbf{7 2 . 1}$ & $\mathbf{5 8 . 2}$ & $\mathbf{5 1}$ \\
\hline
\end{tabular}

Source: Data from National Electoral Commission and Statistical Office of the Republic of Slovenia

If the data for the entire state were considered, the voter turnout in local elections was almost identical in 1998 and 2006 (58.3\% and 58.2\% respectively). Yet, it was lower than in the first elections after the local self-government system had been reinstated (high voter turnout was expected). In the 2002 local elections, the voter turnout was the highest on record. However, the reason for this lies in the presidential elections that were held at the same time. They are usually characterised by a fairly high voter turnout. Based on the voter turnout rate (around 60\%) in the past local elections, one would expect that voter turnout would approximate this rate. However, this was not the case because the 2010 local elections witnessed the lowest voter turnout recorded in the history of the Slovenian local elections. According to Table 2, the voter turnout was somewhat higher in smaller municipalities where the number of residents does not exceed 10,000. Within this group, this was especially true for the subgroup of municipalities with up to 3,000 residents where the majority election system is used. The voter turnout remained the same only in the group of municipalities having 15,000 to 20,000 residents because it was only $0.5 \%$ lower than in the 2006 local elections (52.1\%). In the remaining municipalities, though, the voter turnout was $4-8 \%$ lower than four years before. A record-breaking plunge was witnessed by the two largest municipalities in the country, Ljubljana and Maribor, where the voter turnout in the 2010 local elections was $10.1 \%$ lower than in previous local elections. The trend in the decrease of voter turnout with respect to the size of a municipality continued. The highest turnout was recorded in municipalities having a population of fewer than 3,000 people, whereas the lowest turnout was found in the group of municipalities with a population exceeding 100,000 . 


\subsection{Effectiveness of Parliamentary Political Parties, Non-Partisan Candidates and Lists of Candidates}

The voting systems used for different types of elections exert a strong influence on potential candidacies by non-partisan candidates and candidate lists as well as on the actual possibilities of their successful election. The election system used for elections to the National Assembly of the Republic of Slovenia strongly favours political parties. At the local level, mayoral elections use a two-round absolute majority election system, and municipal council elections use both the majority election system and proportional representation, depending on the size of the municipality in which elections are held.

Running for elected office is an important part of the right to vote when a narrow group of candidates are chosen from among those having the right to be elected. From among the former, voters then choose the most appropriate one(s). If we want to have a democratic election procedure, the candidacies must be as democratic as possible (Grad 1998), and at the same time, the candidate selection itself represents an important stage of the election process. In our analysis, we first concentrate on mayoral elections for which the candidates are nominated by political parties and groups of voters. The number of signatures a group of voters is required to submit in order to officially propose their own candidate is set at a minimum of $2 \%$ of all those who cast a ballot in the first round of the last regular mayoral elections, but this number is to be at least 15 and no more than 2,500 (Article 106 of the Local Elections Act). Non-partisan candidates are able to swiftly enforce their right to be elected, which is also verified by empirical data from the last three local elections in which non-partisan candidates were undisputed winners in mayoral and municipal council elections. In the latter case, a list of candidates for an electoral district can be proposed by a political party or by a group of voters residing in the given electoral district. The number of signatures a group of voters must collect is unique to every municipality. However, it is mandatory that the number of signatures is equal to at least $1 \%$ of the number of voters in the district where they cast a ballot in the most recent regular local elections to a municipal council. The number should not be lower than 15 and not higher than 1,000 (Article 68 of the Local Elections Act). In the 2010 local elections, 778 candidates ran for the posts of mayors, whereas the respective number was 874 in previous local elections. In 2010, there were 26,418 candidates running for municipal council seats, and in 2006, this number was 26,658 . The data on the number of candidates and candidacies indicate a high level of democratic participation because local candidacies are not the exclusive domain of political parties. For example, non-partisan candidates represented $27.4 \%$ of all the candidates for mayor, and $20.3 \%$ of the total number of municipal councillor candidates.

In the section below, we analyse the mayoral elections on the basis of two indicators, namely, (a) the percentage of municipalities where a political party had 
its own candidates for mayors, and (b) the percentage of mayors elected relative to the number of candidacies officially submitted. The comparable results for the first indicator show that all the parliamentary political parties offered their own candidates in just over one-quarter of Slovenian municipalities. However, the percentage of municipalities where parties had independent candidates decreased relative to previous elections - a pattern seen in all parties. 
LEX LOCALIS - JOURNAL OF LOCAL SELF-GOVERNMENT

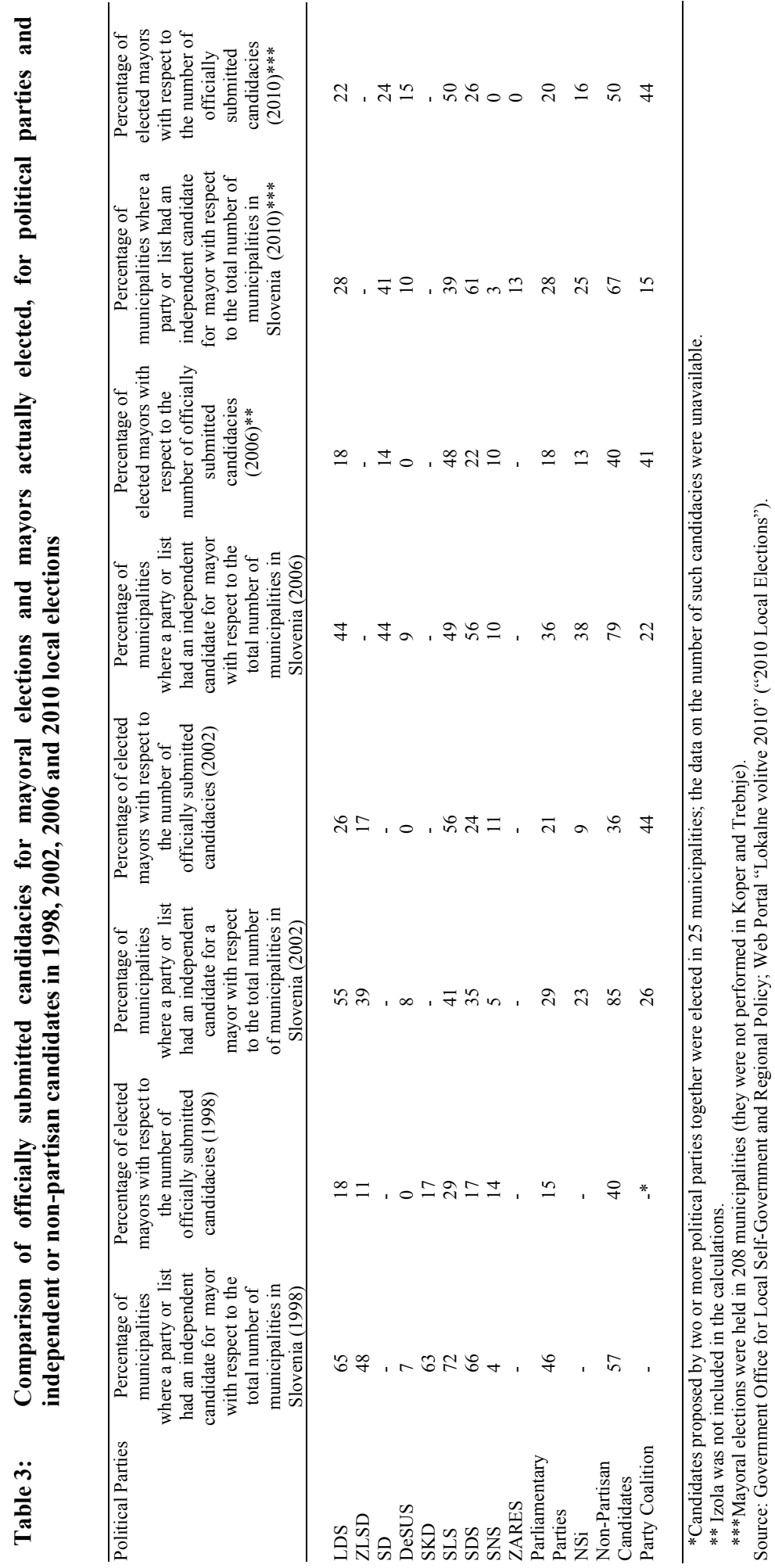


Most candidates (in $61 \%$ of municipalities) were put up by the $\operatorname{SDS}^{5}$ party, followed by the SD party that had candidates in $41 \%$ of municipalities, and by the SLS party that nominated its own candidates in $39 \%$ of municipalities. The analysis of the percentage of elected candidates of the seven parliamentary political parties reveals that during the 1998-2010 period, this portion was between 15 and 21 percent. In the 2010 local elections, though, the eligibility rate of candidates proposed by parliamentary political parties was $2 \%$ higher than in the previous elections. ${ }^{6}$ The second indicator, which represents the percentage of the elected mayors relative to the number of candidacies submitted, shows that the most successful party was SLS (the Slovenian People's Party), reaching a one-half success rate. Out of the 82 proposed candidates, 41 candidates were actually elected. Thus, in the coming four-year term, one-fifth of the Slovenian municipalities are going to be governed by the candidates of the Slovenian People's Party. However, the winners in terms of filling the posts of mayors are once again non-partisan candidates who appeared in $67 \%$ of municipalities, and every other proposed independent candidate was actually elected, meaning that one-third of municipalities (i.e., 70 altogether) are now being led by non-partisan mayors.

If the electoral success rates (measured as a percentage of elected candidates relative to the number of officially submitted candidacies) of parliamentary political parties and non-partisan candidates are compared, it is obvious that the electoral success rates of parliamentary party candidates (with the exception of SNS) and non-partisan candidates have increased. Among the parliamentary political parties, SLS still holds first place. Yet, compared to non-partisan candidates, its advantage gained in the previous local elections (2006) has been lost. Also, the candidates who were supported by a coalition of at least two political parties improved their results because voters elected 14 candidates out of the 32 that were proposed. 


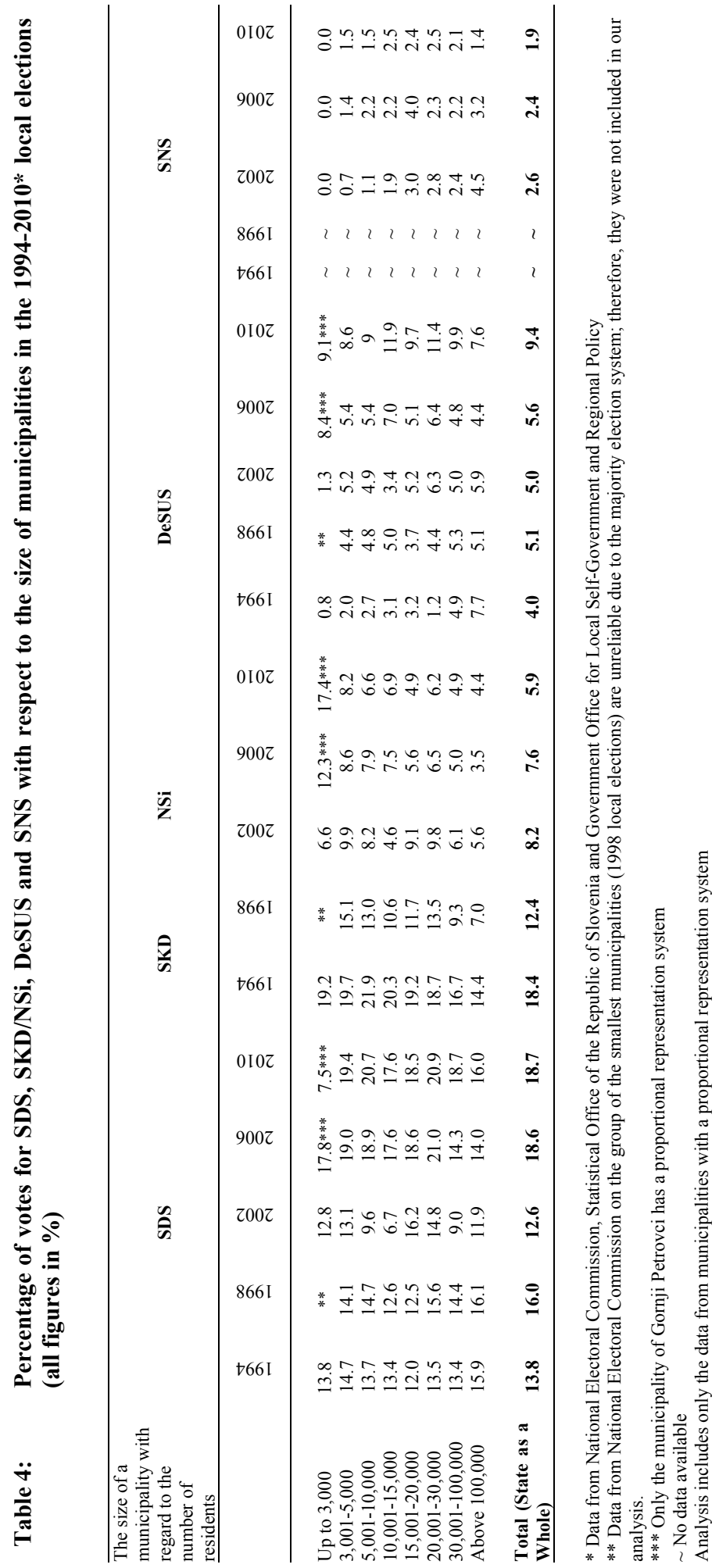




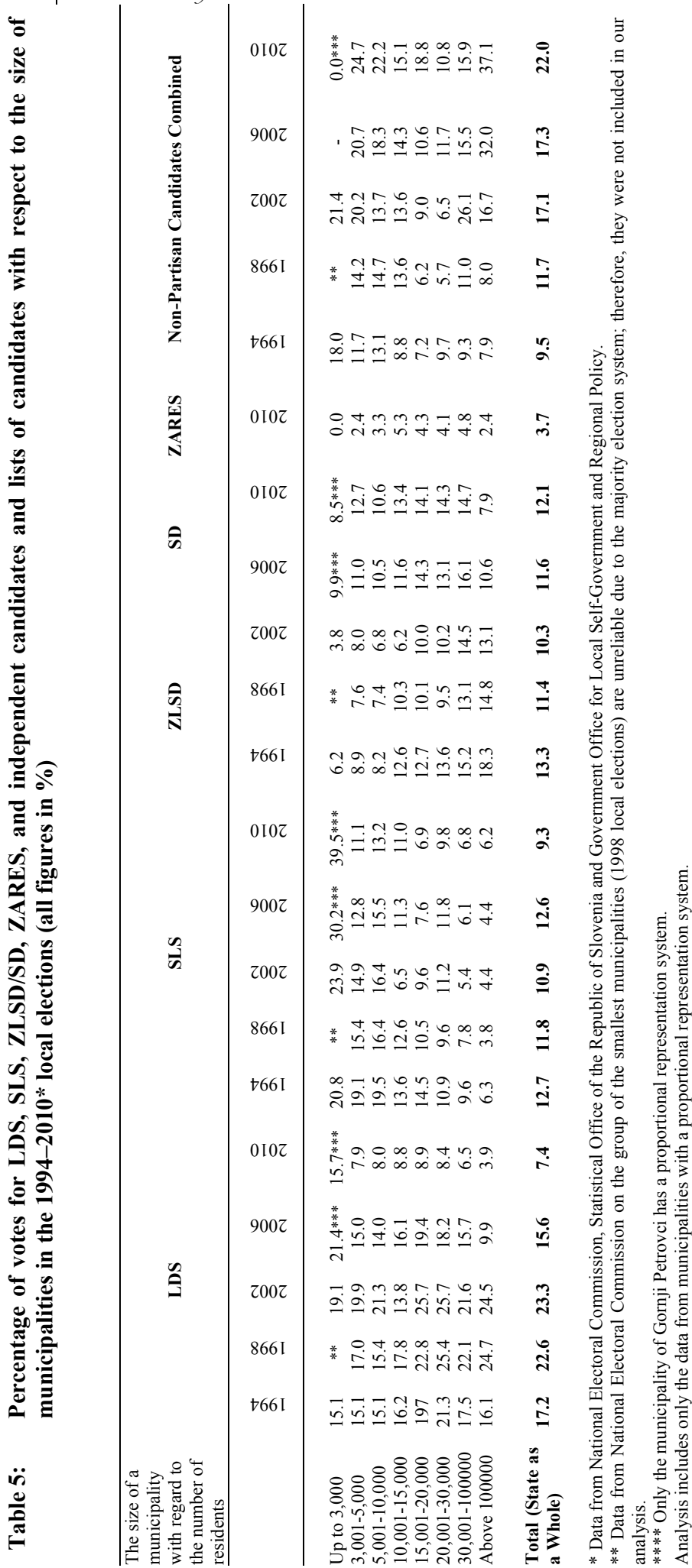


Based on the analysis of the results of municipal council elections during the 1994-2010 period, the political parties and non-partisan lists we analyse can be divided into three groups. The first one, characterised by a constant increase in their proportion of elected candidates, comprises the Democratic Party of Pensioners of Slovenia (DeSUS) and non-partisan lists. The DeSUS party has retained or increased its share in all the elections so far. In the last local election, it managed to increase the proportion of its elected candidates by almost $3 \%$. Nonpartisan lists also continued to increase their number of elected candidates because their initial share ( $9.5 \%$ of elected candidates in the 1994 local election) more than doubled in the last local elections. It is now at $22 \%$. According to the number of the candidates that were successfully elected, the non-partisan lists are now the most successful local-level political group. The second group includes the two parties (specifically $\mathrm{NSi}^{7}$ and SNS) that have been losing their shares of votes since the first local elections. The third group has the most members. It includes the parties whose election results have been unstable. These parties are: Liberal Democracy of Slovenia or LDS, Social Democrats or SD, the Slovenian Democratic Party or SDS, and the Slovenian People's Party or SLS. The greatest loss of votes in this year's local elections (as compared to the preceding ones) was recorded by the Liberal Democratic Party because its vote share was halved. Regarding the number of elected councillors, the only parties it managed to outrun were the ZARES party, New Slovenia or NSi, and the Slovenian National Party or SNS.

Another characteristic detected in all the local elections held so far has been the increasing success of the centre-right political parties. They have gained popularity in smaller municipalities. Hereby, it should not be overlooked that throughout the entire process of local self-government reform, the centre-left political parties were consistently in favour of the formation of somewhat larger municipalities, and they were mostly against further fragmentation of municipalities, while the centre-right political parties were mostly initiators of establishing smaller municipalities.

In the 1994, 1998, and 2002 local elections, non-partisan candidates and lists were usually more successful in smaller municipalities, and they were slightly less successful in larger ones. However, this trend changed with the 2006 local elections in which non-partisan candidates and lists were very successful in large municipalities. This trend also held in the most recent local elections.

According to the data analysis, a decrease in voters' identification with political parties is evident in all the local elections held so far, which entails weakening of ties between voters and parties. The possibility of proposing non-partisan candidates and lists thus serves as a lever that enables people to vote without political parties at the local level. This trend has increased with every local election. The phenomenon of non-partisan candidates is therefore of crucial significance to the democratic performance of municipal councils. The candidate 
personality is given greater salience at the local level (especially when compared to parliamentary elections). In this case, non-partisan candidates have the upper hand because they are not restricted by party politics. Non-partisan candidates enter election campaigns primarily due to their desire to put the local matters in order and not for the sake of implementing the political party programme, to which the candidates backed by political parties must pay attention (Zagorc \& Toplak, 2006: 89). Unlike groups of voters, political parties represent formally regulated institutions by adhering to the predetermined rules of operation. Political parties take part in the political process, and in principle, they are active throughout an entire election period. In this manner, groups of voters cannot be equated with political parties because they are formed shortly before elections. Their work programme is shaped on the basis of the current development within a certain local community.

\section{A Key Emphasis Placed on the Analysis of the 2010 Local Elections Results}

In October 2010, it happened for the first time in the history of Slovenian local elections that the majority was not won by the parties of the current ruling coalition in the parliament, but it was taken over by opposition parties instead. In spite of this, the success of the opposition parties was eclipsed by non-partisan candidates and lists. They further upgraded the trend of their high eligibility that already existed in the preceding local elections. Their success both in mayoral elections and in municipal council elections deserves a separate discussion because they are two different types of elections.

In all the preceding local elections, the percentage of elected non-partisan candidates for mayors with regard to the overall number of such proposed candidacies did not differ significantly $(40 \%, 36 \%$ and $40 \%$ respectively). In the last local elections (2010), however, non-partisan candidates achieved a 50 percent rate of election relative to the total number of such candidacies. Surprisingly, in the last local elections, non-partisan candidates were proposed in fewer municipalities. Yet, they achieved a result that is 10 percent higher than in the 2006 local elections. ${ }^{8}$ Originally, the success of non-partisan candidates was foremost attributed to the specificities of the candidacies in small municipalities (Haček, 2004: 31). However, this thesis was refuted in the 2006 local elections because it became clear that non-partisan candidates posed a serious competition to the candidates proposed by political parties in medium-sized and large municipalities. In this case, the issue of mutual comparability of local elections in local communities of different sizes, which differ in organisational, demographic, and geographic aspects, does not have ultimate significance any longer because success rates of non-partisan candidates and lists have now become relatively high in all the groups of municipalities. 
The success trend among non-partisan candidates and lists at the local level is usually associated with three factors (Haček, 2007: 42). Firstly, in Slovenia, one can detect an explicitly strong tradition of non-partisanship (Lukšič 1994). Apart from this, Slovenian public opinion is strongly opposed to political parties. The degree of trust in political parties has reached its lowest level among political institutions since the beginning of the 1990s. During the local elections in October 2010 , it was only $6 \%$, which was almost one-half of what it was during the period of the 2006 local elections when it reached 11\% (Public Opinion and Mass Communication Research Centre, 2010). The common problem faced by all Slovenian political parties is inadequate structural connections with larger society (Krašovec, 2000: 6). This problem is most frequently expressed by a distinctively negative attitude on the part of the public towards political parties as it follows from the above-mentioned statistical data. Obviously, strong non-partisan mood was also present among the voters at the local level, which was ultimately confirmed by a research project performed by the Faculty of Social Sciences in 2003. It states that only $2.7 \%$ of the voters trust the political parties in their municipality. ${ }^{9}$

Secondly, at the national level, non-partisan candidates have almost no real chance of being elected to the National Assembly due to the existing election system, and because of the emphatic role of the political parties in competing for entering the national parliament. Thus, their last chance to successfully enforce the right to be elected in Slovenia lies in their candidacies for local elections. After all, the majority election system (used for mayoral elections) is much more favourable (for non-partisan candidates) than the proportional representation system at the national level of government (Haček, 2007: 42).

Thridly, due to their narrower scope, local elections are more suitable for lists and non-partisan candidates to enforce the right to be elected. Namely, in local elections, voters tend to vote for the candidates and lists that come from the communities they themselves originate from, and where they live. In so doing, adherence to a party does not play as an important role as it does at the national level. The candidacy and successful election of a candidate not bound by any party also contribute to a greater feeling among the local population that can actually enforce its right to local self-government within its own municipality (ibid.).

Since the most recent 1994 local elections, it has become evident that there is a growing trend in favour of non-partisan candidates and lists that have as a rule become more successful than well-established political parties in almost all types of municipalities. Thus, for an average voter, the supposed partisan independence of a candidate has become the second most important feature they value right after his/her political experience. ${ }^{10}$ Interestingly, an average Slovenian voter ranks the importance of a candidate's independence for his/her voting choice higher than the candidate's adherence to a political party, and even higher than his/her personal acquaintance with the candidate. In comparison with parliamentary elections, the 
candidate's party adherence, as far as local elections are concerned, is much less relevant to an average Slovenian voter. ${ }^{11}$

The reservation regarding the actual independence of individual candidates and lists has often been proven as justified. If we focus solely on the last mayoral elections when 70 candidates who had declared themselves independent were elected, it is obvious that there were at least two-dozen elected candidates who were once, or still are, (prominent) members of parliamentary political parties, some among them even being the National Assembly members. True independence of some of them could in fact be questioned. No different picture could be extracted from the overview of successful non-partisan lists because some of them were undoubtedly made in secrecy by political parties, a fact that was clearly revealed during the coalition-building processes which the newly elected municipal councils had undergone.

So, the trend already recorded in the 2006 local elections did not change significantly during the 2010 local elections. Moreover, the position of nonpartisan candidates and lists has now become well-established and even stronger than political parties. They lost their support already in the preceding local elections. And they really only intensified such a negative trend. The analysed data serve as a strong warning to political parties for the next local elections if according to the current trends, they will have to invest more effort in gaining voters' trust, or to come to terms with the fact that local communities refuse the politicisation of decision-making on local-level matters, which, last but not least, concern only the residents of local communities.

\section{Notes}

${ }^{1}$ The term "non-partisan candidate" is used to designate the candidates proposed by the groups of voters. By using the term "non-partisan lists," we mean those lists that were not registered as political parties or recorded as such in the register of political parties of the Ministry of the Interior on the day of the first round of local elections, i.e., on October 10, 2010.

${ }^{2}$ Act on Amending the Local Government Act, Official Journal of the Republic of Slovenia, No. 51/2010, June 28, 2010.

${ }^{3}$ Article 9 of the Local Elections Act, Official Journal of the Republic of Slovenia, No. 94/2007, October 16, 2007.

${ }^{4}$ Research Project "Standpoints on Local Democracy," Centre for Political Science Research, Faculty of Social Sciences (N=1093), 2003.

${ }^{5}$ For reasons of enhanced legibility, we henceforth use the official acronyms of Slovenian political parties as follows: SDS (Slovenska demokratska stranka/Slovenian Democratic Party), SD (Socialni demokrati/Social Democrats), SLS (Slovenska ljudska stranka/Slovenian People's Party), NSi (Nova Slovenija/New Slovenia), LDS (Liberalna demokracija Slovenije/Liberal Democracy of Slovenia), DeSUS (Demokratična stranka upokojencev Slovenije/Democratic Party of Pensioners of Slovenia), and SNS (Slovenska nacionalna stranka/Slovenian National Party). 
${ }^{6}$ In all the preceding local elections, the structure of parliamentary political parties had not changed. However, in the last National Assembly elections, a change occurred because the NSi party failed to pass the parliamentary threshold. Greater support was won by the then newly established party ZARES, which first appeared with its own candidates in the 2010 local elections.

${ }^{7} \mathrm{NSi}$ was actually established in 2000 . However, we treat it as a successor to the SKD party (Slovenski krščanski demokrati - Slovenian Christian Democrats).

${ }^{8}$ Thus, in 2006, out of 166 proposed non-partisan candidates for mayors, 67 were elected. And in 2010, there were 70 elected out of 140 proposed non-partisan candidates.

${ }^{9}$ Question 3.40: "From among the stated entities, whom do you trust the most?" Answers: the mayor $(45.5 \%)$, the municipal council $(21.5 \%)$, municipal administration $(5.0 \%)$, political parties (2.7\%), don't know (25.2\%). N=1093. Source: Research Project "Standpoints on Local Democracy," Centre for Political Science Research, Faculty of Social Sciences, 2003.

${ }^{10}$ Question 3.20: "How important to you are the following candidate characteristics when you are to decide in local elections? For every statement, please choose a mark from 1 to 5 , whereby 1 means "not important at all" and 5 means "very important." Average values of answers are as follows: for "a) membership in a political party" 2.90 , "b) political experience" 3.90 , "c) gender" 1.78 , "d) personal acquaintance with a candidate" 2.56 and for "e) candidate's independence" 3.23. N=1093. Source: Research Project "Standpoints on Local Democracy", Centre for Political Science Research, Faculty of Social Sciences, 2003. ${ }^{11}$ Question 3.21: "When choosing among candidates, is party adherence more important to you in local or in parliamentary elections?" Answers: "More important in parliamentary elections" $(26.2 \%)$, "Equally important or unimportant" $(49.9 \%)$, "More important in local elections" (6.8\%) and "Don't know, can't decide" (17.2\%). N=1093. Source: Research Project "Standpoints on Local Democracy," Centre for Political Science Research, Faculty of Social Sciences, 2003.

\section{References}

Bačlija, I. (2007) Analysing the formation of new municipalities and the first local elections in these municipalities, Lex Localis - Journal of Local Self-Government 5(1), pp. 4764.

Cassel, A. C. (1987) The nonpartisan ballot and the decline of American parties: A contextual effect?, Political behaviour, 9(3), pp. 246-56, doi: 10.1007/BF00988614.

Grad, F. (1998) Lokalna demokracija: organizacija in volitve (Ljubljana: Uradni list RS).

Grad, F. (2001) Lokalni organi, In: Vlaj, S. (ed.) Vodnik po slovenski lokalni samoupravi, pp. 47-59, (Ljubljana: Inštitut za lokalno samoupravo pri Visoki upravni šoli).

Haček, M. (2004) Lokalne volitve zgolj indikator za parlamentarne?, In: Brezovšek, M., Haček, M. \& Krašovec, A. (eds) Lokalna demokracija I: analiza lokalnih volitev 2002, pp. 22-35 (Ljubljana: Fakulteta za družbene vede).

Haček, M. (2007) Local elections - still merely second-class elections?, Lex localisJournal of Local Self-Government, 5(1), pp. 31-45.

Holmberg, S. (2003) Are political parties necessary?, Electoral studies, 22(2), pp. 287-299, doi: 10.1016/S0261-3794(02)00016-1.

Krašovec, A. (2000) Moč v političnih (Ljubljana: Fakulteta za družbene vede).

Lukšič, I. (1994) (Ne)strankarstvo na Slovenskem, In: Lukšič, I. (ed.) Stranke in strankarstvo, Zbornik referatov Slovenskega politološkega društva (Ljubljana: Slovensko politološko društvo). 
Mill, J. S. (1991) On Liberty and Other Essays (Oxford: Oxford University Press).

Northup, N. (1987) Local nonpartisan elections, political parties and the first amendment, Columbia Law Review, 87(8), pp. 1677-1701.

Public Opinion and Mass Communication Research Centre (2010) Politbarometer 10/2010. Ljubljana: Public Opinion and Mass Communication Research Centre, available at: http://www.cjm.si/PB_rezultati (November 20, 2010).

Schaffner, F. B., Streb, M \& Wright, G. (2001) Teams without uniforms: The nonpartisan ballot in state and local elections, Political research quarterly 54(1), pp. 7-30, doi: $10.1177 / 106591290105400101$.

Statistical Office of the Republic of Slovenia (2007) Lokalne volitve 1994-2006 (19942006 Local Elections), available at: http://www.stat.si/doc/pub/06-RP-078-0701.pdf (November 15, 2010).

Stoker, G. (1996) Redefining Local Democracy, In: Pratchett L. \& Wilson D. (eds) Local Democracy and Local Government, pp. 188-209 (Basingstoke: Macmillan).

Stoker, G. (2004) New Localism, Participation and Networked Community Governance (Manchester: University of Manchester).

Zagorc, S. \& Toplak J. (2006) Standing as candidates in local elections: a lack of democratic feeling in Local elections act (ZLV-F), Lex Localis - Journal of Local SelfGovernment, 4(2), pp. 89-109. 